\title{
ANALISIS PENGARUH PENGGUNAAN DANA ZAKAT TERHADAP PEMBERDAYAAN MASYARAKAT \\ Studi pada Badan Amil Zakat dan Lembaga Amil Zakat di Yogyakarta
}

\author{
Ufi Nida Ussolikhah \\ Khusnul Hidayah
}

\begin{abstract}
This research explains the problem whether the used of zakat funds against Badan Amil Zakat and Lembaga Amil Zakat in Yogyakarta have effect toward society empowerment. This research aim is to obtain empirical evidence of the effect of using zakat fund in Badan Amil Zakat and Lembaga Amil Zakat in Yogyakarta. The data used in this research is primary data. The sampling technique is purposive sampling. Whereas, the method used to gather data is interview and questionnaire. The data were analyzed using validity test, reliability test, classical assumption test and regression test. The result of this research were processed usig SPSS program version 16 for windows indicate the effect of using zakat funds towards society empowerment. It obtained $Y=20,089+1,294 Y$ as regression equation. Based on regression equation, the independent variable will change 1,294 for each change in unit of independent variable. In the conclusion, the variable of used zakat fund has an effect toward society empowerment.
\end{abstract}

Keywords : used of zakat fund, society empowerment

\section{PENDAHULUAN}

Zakat merupakan ibadah dan kewajiban sosial bagi kaum muslimin yang kaya (aghniya') ketika memenuhi nisab (batas minimal) dan hawl (waktu satu tahun). Secara sosiologis zakat bertujuan untuk memeratakan kesejahteraan dari orang kaya kepada yang miskin secara adil dan mengubah penerima zakat menjadi pembayar zakat (Hadi, 2010: 1). Zakat dalam pelaksanaannya diatur oleh agama dan negara, baik dari segi jenis harta yang dizakatkan, para wajib zakat (muzakki) maupun para penerima zakat (mustahik), sampai pada pengelolanya dalam hal ini pemerintah atau lembaga yang ditunjuk oleh pemerintah untuk mengelola zakat demi kemaslahatan bersama.

Ketentuan hukum mengenai zakat ditetapkan dan dikembangkan dengan merumuskan kembali hal-hal yang berhubungan dengan sumber zakat (harta yang wajib dizakati) dan penggunaan (pendistribusian) zakat yang ditopang oleh manajemen yang baik, maka peran dan fungsi zakat akan dapat terwujud (Asnaini, 
2008: 4). Ketentuan tersebut akan dapat terwujud apabila pengelolaan zakat dilakukan secara profesional. Pengelolaan zakat secara profesional memerlukan tenaga yang terampil, dan menguasai masalah yang berhubungan dengan zakat, seperti muzakki, nisab, hawl, dan mustahik zakat (Hadi, 2010: 173).

Sumber zakat merupakan suatu ketentuan bahwa seseorang dapat menggunakan harta yang telah diperoleh, sehingga dapat membersihkan dan mensucikan harta tersebut. Sumber zakat memberi manfaat bahwa zakat dapat menentramkan jiwa seseorang yang telah menunaikannya. Penggunaan zakat merupakan suatu tambahan dan pengembang harta bagi masyarakat kurang mampu bahwa masyarakat dapat memanfaatkan dana tersebut untuk meningkatkan taraf hidup, sehingga dapat mengurangi angka kemiskinan. Allah SWT berfirman: "Hendaklah orang yang mampu memberi nafkah menurut kemampuannya. Dan orang yang disempitkan rezekinya hendaklah memberi nafkah dari harta yang diberikan Allah kepadanya. Allah tidak memikulkan beban kepada seseorang melainkan (sekedar) apa yang Allah berikan kepadanya. Allah kelak akan memberikan kelapangan sesudah kesempitan" (Qs.al-Thalaq (65): 7).

Perkembangan zakat di Indonesia sangat menggembirakan dalam lima tahun terakhir ini. Potensi zakat yang selalu berkembang tersebut dapat digunakan untuk pemberdayaan masyarakat. Penelitian tentang pengelolaan dana zakat pernah dilakukan sebelumnya, diantaranya oleh Ardhanaraswari (2010) menguji tentang analisis sumber dan penggunaan dana zakat yang berpengaruh terhadap pemberdayaan masyarakat. Sampel yang diambil pada penelitian ini adalah dompet peduli ummat Daarut Tauhiid Bandung. Hasil penelitian ini menunjukkan bahwa sumber dan penggunaan dana zakat berpengaruh signifikan terhadap pemberdayaan masyarakat. Penelitian yang dilakukan Putra (2010) tentang pengaruh pendayagunaan zakat produktif terhadap pemberdayaan mustahik, diperoleh hasil bahwa ada pengaruh signifikan pendayagunaan zakat produktif mempunyai andil dalam mempengaruhi pemberdayaan mustahik.

Alasan memilih Yogyakarta sebagai objek penelitian karena garis kemiskinan pada Maret 2013 adalah Rp283.454,- per kapita per bulan. Jika dibandingkan dengan kondisi Maret 2012 yang garis kemiskinannya sebesar Rp260.173,- per 
kapita per bulan, terjadi kenaikan sebesar 8,95\% dan jika dibandingkan dengan kondisi September 2012 yang besarnya Rp 70.110,- per kapita per bulan, maka tampak adanya kenaikan garis kemiskinan sebesar 4,94\%. Terjadinya peningkatan garis kemiskinan ini sejalan dengan terjadinya inflasi maret 2012 ke Maret 2013 yang sebesar 6,36\%, serta inflasi September 2012 - Maret 2013 sebesar 3,98\% (BPS: 2013).

\section{TINJAUAN PUSTAKA DAN PENGEMBANGAN HIPOTESIS}

\section{Zakat}

Menurut Ibrahim Usman Asy-Sya'ian dalam Asnaini (2008: 26) mengertikan zakat adalah memberikan hak milik harta kepada orang yang fakir yang muslim, bukan keturunan hasyim dan buka budak yang telah dimerdekakan oleh keturunan Hasyim, dengan syarat terlepasnya manfaat harta yang telah diberikan itu dari pihak semula, dari semua aspek karena Allah. Menurut Undang-Undang Nomor 23 Tahun 2011 tentang pengelolaan zakat. Zakat adalah harta yang wajib dikeluarkan oleh seorang muslim atau badan usaha untuk diberikan kepada yang berhak menerimanya sesuai dengan syariat Islam.

\section{Penggunaan dana}

Menurut Tim Penyusun Pedoman Akuntansi Organisasi Pengelola Zakat (2005: 67) dalam Ardhareswari (2010: 7) penggunaan dana adalah pengurangan sumberdaya organisasi baik berupa kas maupun non kas dalam rangka penyaluran, pembayaran beban, atau pembayaran utang. Penggunaan dana zakat melalui lembaga amil zakat dapat disalurkan untuk fakir, miskin, iqab, orang yang terlilit utang (gharim), muallaf, fisabilillah, orang yang dalam perjalanan (Ibnu sabil), dan amil.

\section{Pemberdayaan masyarakat}

Menurut Kartasismita (1996) dikutip dalam Huri et al., (2008: 87) menambahkan bahwa pemberdayaan masyarakat dapat diartikan sebagai upaya untuk membangun daya dengan mendorong, memberikan motivasi, dan membangkitkan kesadaran akan potensi yang dimilikinya serta berupaya untuk 
mengembangkannya. Menurut Permendagri RI Nomor 7 Tahun 2007 tentang Kader Pemberdayaan Masyarakat, dinyatakan bahwa pemberdayaan masyarakat adalah suatu strategi yang digunakan dalam pembangunan masyarakat sebagai upaya untuk mewujudkan kemampuan dan kemandirian dalam kehidupan bermasyarakat, berbangsa dan bernegara.

Secara umum upaya untuk mengatasi kemiskinan adalah dengan memberikan suatu rangsanagan sehingga dapat mendorong masyarakat agar dapat memberdayakan potensi yang ada. Menurut Huri et al., (2008: 85) pemberdayaan dalam hal menanggulangi kemiskinan dapat dilakukan secara bertahap yaitu

1. Fase inisial, adalah suatu proses pemberdayaan yang berasal dari pemerintah, oleh pemerintah dan diperuntukkan bagi rakyat. Rakyat bersifat pasif, melaksanakan apa yang direncanakan pemerintah dan tetap bergantung pada pemerintah.

2. Fase partisipatoris, yaitu suatu proses pemberdayaan berasal dari pemerintah bersama masyarakat dan diperuntukkan bagi rakyat. Masyarakat sudah dilibatkan secara aktif dalam kegitan pembangunan untuk menuju kemandirian.

3. fase emansipatoris adalah proses pemberdayaan berasal dari rakyat, oleh rakyat, dan untuk rakyat dengan didukung oleh pemerintah. Masyarakat sudah menemukan kekuatan dirinya, sehingga dapat melakukan pembaharuan dalam mengaktualisasi diri.

\section{Pengaruh Penggunaan Dana Zakat terhadap Pemberdayaan Masyarakat}

Penggunaan dana zakat merupakan seatu faktor penentu keberhasilan pemberdayaan masyarakat agar dapat digunakan untuk meningkatkan kualitas hidup. Dengan adanya pemberdayaan tersebut akan meningkatkan pendapatan masyarakat yang pada akhirnya dapat mengubah penerima zakat menjadi pembayar zakat. Penelitian yang dilakukan oleh Putra (2010) menunjukkan adanya pengaruh antara penggunaan dana zakat terhadap pemberdayaan. berdasarkan penelitian yang dilakukan oleh Putra (2010) dan uraian di atas, peneliti menduga bahwa dengan adanya pengelolaan penggunaan dana zakat yang profesional akan dapat 
meningkatkan pemberdayaan masyarakat. Hipotesis yang dapat diajukan adalah: $\mathrm{H}_{1}$ : Penggunaan dana zakat berpengaruh terhadap pemberdayaan masyarakat.

\section{Rerangka Pemikiran}

Rerangka penelitian dalam penelitian ini digunakan untuk menjelaskan pengaruh variabel independen terhadap veriabel dependen. Gamber rerangka pemikiran ini adalah:

penggunaan dana zakat

\section{Gambar 1 \\ Rerangka Pemikiran}

\section{METODA PENELITIAN}

\section{Populasi dan sampel}

Populasi dalam penelitian ini yaitu Mustahik Badan Amil Zakat dan Lembaga Amil Zakat di Yogyakarta. Berdasarkan populasi yang ada akan diambil sejumlah sampel yaitu mustahik Badan Amil Zakat Provinsi DIY dan Lazis UII. Teknik pengambilan sampel yang digunakan dalam penelitian adalah metoda purposive sampling. Kriteria dalam pengambilan sampel ini adalah mustahik yang memperoleh dana zakat untuk usaha produktif dan peningkatan ekonomi keluarga pada Badan Amil Zakat Profinsi DIY dan LAZIS UII.

\section{Definisi operasional dan pengukuran variabel}

\section{Variabel Penggunaan Dana Zakat}

Menurut Tim Penyusun Pedoman Akuntansi Organisasi Pengelola Zakat (2005: 67) dalam Ardhareswari (2010: 7) penggunaan dana adalah pengurangan sumberdaya organisasi baik berupa kas maupun non kas dalam rangka penyaluran, pembayaran beban, atau pembayaran utang. Variabel penggunaan dana zakat menggunakan intrumen Putra (2010) yang diukur dengan 5 skala Likert.

\section{Variabel Pemberdayaan Masyarakat}

Menurut Bryant dan White (1987) dikutip dalam Huri et al., (2008: 85) pemberdayaan masyarakat adalah penumbuhan kekuasaan dengan wewenang yang 
lebih besar kepada si miskin. Menurut mereka, satu-satunya cara menciptakan mekanisme dari dalam guna meluruskan keputusan-keputusan alokasi yang sangat adil adalah menjadikan rakyat mempunyai pengaruh. Menurut Kartasismita (1996) dikutip dalam Huri et al., (2008: 87) menambahkan bahwa pemberdayaan masyarakat dapat diartikan sebagai upaya untuk membangun daya dengan mendorong, memberikan motivasi, dan membangkitkan kesadaran akan potensi yang dimilikinya serta berupaya untuk mengembangkannya. Variabel pemberdayaan masyarakat dalam penelitian ini adalah dana zakat untuk penguatan ekonomi keluarga dengan diukur berdasarkan 5 skala likert.

\section{Teknik Analisis Data}

\section{Uji Kualitas Data}

Menurut Ghozali (2011: 52) uji validitas digunakan untuk mengukur sah atau tidaknya suatu kuesioner. Suatu kuesioner dikatakan valid jika pertanyaan pada kuesioner mampu untuk mengungkapkan sesuatu yang akan diukur oleh kuesioner tersebut.

Sementara itu, menurut Ghozali (2011: 47) uji reliabilitas adalah alat untuk mengukur suatu kuesioner yang merupakan indikator dari variabel atau konstruk. Suatu kuesioner dikatakan reliabel atau handal jika jawaban seseorang terhadap pernyataan adalah konsisten atau stabil dari waktu ke waktu.

\section{Analisis Regresi Berganda}

Metoda yang digunakan untuk menguji hipotesis penelitian ini dengan menggunakan analisis regresi sederhana. Menurut Ghozali (2011: 96) analisis regresi adalah penggunaan analisis untuk mengukur dua variabel atau lebih, juga menunjukkan hubungan antara veriabel dependen dengan variabel independen. Langkah-langkah dalam regresi linier berganda adalah:

\section{a. Uji Asumsi Klasik}

\section{Uji Normalitas}

Menurut Ghozali (2011: 160) uji normalitas bertujuan untuk menguji dalam model regresi, variabel pengganggu atau residual memiliki distribusi normal. Uji statistik untuk menguji normalitas data dalam penelitian ini menggunakan uji 
Kolmogorov Smirnov dengan tingkat signifikansi sebesar 0,05. jika hasil yang diperoleh lebih besar dari 0,05 maka dapat disimpulkan bahwa data residual tidak berdistribusi normal.

\section{Uji Multikolinearitas}

Menurut Ghozali (2011: 105) uji multikolinearitas bertujuan untuk menguji model regresi ditemukan adanya korelasi antara variabel bebas (independen). Model yang baik seharusnya tidak terjadi korelasi di antara variabel independen. Jika variabel independen saling berkorelasi, maka variabel-variabel ini tidak ortogonal. Ada tidaknya multikolinearitas dalam suatu regresi, dapat dilihat melalui nilai variance inflation factor (VIF) dengan tingkat toleransi sebesar $1 \%(0,10)$.

\section{Uji Heteroskedastisitas}

Menurut Ghozali (2011: 139) uji heteroskedastisitas bertujuan menguji dalam model regresi terjadi ketidaksamaan varian dari residual satu pengamatan ke pengamatan yang lain. Untuk menguji ada tidaknya heteroskedastisitas dengan menggunakan uji Glejser. Gejala heteroskedastisitas dapat dideteksi dengan membandingkan tingkat signifikansi $\alpha=5 \%$ dengan tingkat signifikansi t. Apabila signifikansi t lebih besar dari tingkat signifikansi $\alpha=5 \%$, maka tidak terjadi heteroskedastisitas.

\section{Uji Autokorelasi}

Menurut Ghozali (2011: 110) uji autokorelasi bertujuan menguji dalam model regresi linier ada korelasi antara kesalahan pengganggu pada perioda t dengan kesalahan pengganggu pada perioda t-1 (sebelumnya). Jika terjadi korelasi, maka disebut dengan problem autokorelasi. Pendeteksian ada atau tidaknya autokorelasi dengan menggunakan uji Durbin Watson.

\section{Analisis Statistik Diskiptif}

Menurut Ghozali (2011: 19) statistik diskriptif memberikan gambaran atau diskiptif suatu data yang dilihat dari nilai rata-rata (mean), standar deviasi, varian, maksimum, minimum, sum, range, kurtosis, dan skewness. Tujuan Statistik 
diskiptif pada penelitian ini untuk memberikan gambaran atau deskriptif atas data yang dikumpulkan.

\section{b. Uji Hipotesis}

\section{Koefisien Determinasi (Adjusted R Square)}

Menurut Ghozali (2011: 97) koefisien determinasi $\left(\mathrm{R}^{2}\right)$ pada intinya mengukur kemampuan model dalam menerangkan variasi variabel dependen. Nilai koefisien determinasi adalah antara nol dan satu. Nilai $\mathrm{R}^{2}$ yang kecil berarti kemampuan variabel-variabel independen dalam menjelaskan variasi variabel dependen sangat terbatas. Nilai yang mendekati satu berarti variabel-variabel independen memberikan hampir semua informasi yang dibutuhkan untuk memprediksi variasi variabel dependen.

\section{Uji F}

Menurut Ghozali (2011: 98) uji statistik F pada dasarnya menunjukkan apakah variabel independen yang dimasukkan dalam model mempunyai pengaruh secara bersama-sama terhadap veriabel dependen.

\section{Uji t}

Menurut Gozali (2011: 64) uji statistik t digunakan untuk menentukan apakah dua sampel yang tidak berhubungan memiliki nilai rata-rata yang berbeda.

\section{HASIL DAN PEMBAHASAN}

Tabel 1 menunjukkan bahwa dari 30 responden terdapat 19 pria $(63,3 \%)$ dan 11 wanita $(36,7 \%)$. Umur responden penelitian ini terdiri dari 25-30 tahun sebanyak 1 orang $(3,3 \%), 31-35$ tahun sebanyak 9 orang (30\%), 36-40 tahun sebanyak 8 orang $(26,7), 41-45$ tahun sebanyak 9 orang (30\%), >45 tahun sebanyak 3 orang (10\%). Status perkawinan responden kawin sebanyak 28 orang $(93,3 \%)$ dan belum kawin sebanyak 2 orang (6,7\%). Responden penelitian ini terdiri dari pendidikan SD sebanyak 8 orang (26,7\%), SMP sebanyak 4 orang (13,3\%), SMA 17 orang $(56,7 \%)$, dan $\mathrm{S} 1$ sebanyak 1 orang $(3,3 \%)$. 
Tabel 1

Karakteristik Responden Penelitian

\begin{tabular}{|c|c|c|c|c|c|}
\hline Karakteristik & Jumlah & $\%$ & Karakteristik & Jumlah & $\%$ \\
\hline $\begin{array}{c}\text { Jenis Kelamin } \\
\text { Pria }\end{array}$ & 19 & 63,3 & Status Perkawinan & & \\
Wanita & 11 & 36,7 & Kelum kawin & 28 & 93,3 \\
\hline Jumlah & 30 & 100 & Jumlah & 30 & 100 \\
\hline Umur & & & Pendidikan & & \\
$25-30^{\text {th }}$ & 1 & 3,3 & SD & 8 & 26,7 \\
$31-35^{\text {th }}$ & 9 & 30 & SMP & 4 & 13,3 \\
$36-40^{\text {th }}$ & 8 & 26,7 & SMA & 17 & 56,7 \\
$41-45^{\text {th }}$ & 9 & 30 & S1 & 1 & 3,3 \\
$>45^{\text {th }}$ & 3 & 10 & & & \\
\hline Jumlah $^{\text {Sum }}$ & 30 & 100 & Jumlah & 30 & 100 \\
\hline
\end{tabular}

Sumber: Data primer, diolah (2014)

\section{Uji Instrumen Penelitian}

Berdasar uji validitas dapat dilihat bahwa masing-masing item pertanyaan memiliki nilai $r$ hitung $>r$ tabel $(0,361)$. Sehingga dapat disimpulkan semua item pertanyaan dinyatakan valid. Sementara itu, uji reliabilitas menunjukkan bahwa seluruh variabel penelitian memberikan nilai cronbach alpha lebih besar dari 0,07, yang artinya reliabel.

\section{Uji Asumsi Klasik}

\section{Uji normalitas}

Hasil uji normalitas pada tabel 2 menunjukkan nilai Kolmogorov Smirnov 0,833 yang lebih besar dari 0,05. Berdasar hasil tersebut, diketahui bahwa data berdistribusi normal.

Tabel 2

Uji Normalitas

\begin{tabular}{|l|l|}
\hline Uji Kolmogorov-smirnov & Unstandarize Residual \\
\hline Nilai Kolmogorov-Smirnov & 0,623 \\
\hline Sig & 0,833 \\
\hline
\end{tabular}

Sumber: Data primer, diolah (2014) 


\section{Uji Multikolinieritas}

Hasil pengujian multikolinieritas yang menunjukkan nilai variance inflation factor (VIF) variabel, yaitu pendayagunaan zakat produktif adalah 1,000 yang lebih kecil dari 10. Berdasar hasil tersebut, diketahui bahwa antar variabel independen tidak terjadi persoalan multikolinieritas.

Tabel 3

Uji Multikolinearitas

\begin{tabular}{|l|c|c|}
\hline \multirow{2}{*}{ Model } & \multicolumn{2}{|l|}{ Collinearity Statistics } \\
\cline { 2 - 3 } & Tolerance & VIF \\
\hline $\begin{array}{l}\text { 1 (Constant) } \\
\text { Penggunaan } \\
\text { Dana Zakat }\end{array}$ & 1.000 & 1.000 \\
\hline
\end{tabular}

Sumber: Data primer, diolah (2014)

\section{Uji Heteroskedastisitas}

Berdasar nilai VIF untuk variabel penggunaan dana zakat terhadap pemberdayaan masyarakat sebesar $1.000<5$. Berdasar hasil tersebut, diketahui bahwa model tersebut tidak ada multikolinearitas.

Tabel 4

Uji Heteroskedastisitas

\begin{tabular}{|c|l|l|l|l|}
\hline & & & \multicolumn{2}{|c|}{$\begin{array}{c}\text { Collinearity } \\
\text { Statistics }\end{array}$} \\
\cline { 3 - 5 } Model & $\mathbf{t}$ & Sig. & Tolerance & VIF \\
\hline $\begin{array}{c}\text { 1 (Constant) } \\
\text { Penggunaan } \\
\text { dana zakat }\end{array}$ & 1.593 & .122 & 1.000 & 1.000 \\
\hline
\end{tabular}

Sumber: Data primer, diolah (2014)

\section{Uji Autokorelasi}

Hasil pengujian dengan menggunakan uji Durbin-Watson atas residual persamaan regresi, diperoleh nilai Durbin Watson 1,603. Sedangkan nilai dL dan dU dari tabel Durbin-Watson dengan $\alpha=5 \%, n=30$ dan $\mathrm{K}=2$ menunjukkan nilai $\mathrm{dL}=1,255$ dan $\mathrm{dU}=1,560$. Nilai $4-\mathrm{dL}=4-1,255=2,745$ dan nilai 4-dU=4-1,560= 2,44. Dengan demikian, diketahui bahwa tidak terdapat autokorelasi. 
Tabel 5

Uji Autokorelasi

\begin{tabular}{|c|c|c|c|c|c|}
\hline Model & $\boldsymbol{R}$ & $\boldsymbol{R}$ Square & $\begin{array}{c}\text { Adjusted } \boldsymbol{R} \\
\text { Square }\end{array}$ & $\begin{array}{c}\text { Std. Error of } \\
\text { the Estimate }\end{array}$ & $\begin{array}{c}\text { Durbin- } \\
\text { Watson }\end{array}$ \\
\hline 1 & $.486^{\mathrm{a}}$ & .236 & .209 & 7,187 & 1,603 \\
\hline
\end{tabular}

Sumber: Data primer, diolah (2014)

\section{Uji Hipotesis}

\section{Koefisien determinasi $\left(\mathbf{R}^{2}\right)$}

Hasil koefisien determinasi meunjukkan nilai $\mathrm{R}$ sebesar 0,236 yang berarti kemampuan veriabel penggunaan dana zakat terhadap pemberdayaan masyarakat kurang baik karena nilai yang diperoleh kuarang dari sattu. Hasil adjusted $R$ square sebesar 0,209 atau 20,9\% faktor yang mempengaruhi pemberdayaan masyarakat dapat dijelaskan oleh faktor penggunaan dana zakat. Sedangkan 79,1\% (100\%20,9) dipengaruhi oleh faktor lain yang tidak diteliti.

Tabel 6

Koefisien Determinasi

\begin{tabular}{|l|l|l|l|l|l|}
\hline Model & $\boldsymbol{R}$ & $\boldsymbol{R}$ Square & $\begin{array}{l}\text { Adjusted } \\
\boldsymbol{R} \text { Square }\end{array}$ & $\begin{array}{l}\text { Std. Error of } \\
\text { The Estimate }\end{array}$ & $\begin{array}{l}\text { Durbin- } \\
\text { Watson }\end{array}$ \\
\hline 1 & .486 & .236 & .209 & 7,187 & 1,603 \\
\hline
\end{tabular}

Sumber: Data primer, diolah (2014)

\section{Analisis Regresi}

Pengujian penggunaan dana zakat terhadap pemberdayaan masyarakat ini akan menunjukkan bahwa penggunaan dana zakat berpengaruh terhadap pemberdayaan masyarakat, adapun pengujian statistik menggunakan SPSS dengan menggunakan alpa $(\alpha)$ sebersar 5\% sebagai berikut:

Tabel 7

Anova

\begin{tabular}{|c|c|c|c|c|c|}
\hline Model & Sum of Squares & $\boldsymbol{d} \boldsymbol{f}$ & Mean Square & $\boldsymbol{F}$ & Sig. \\
\hline Regression & 447.592 & 1 & 447.592 & 8,665 &, 006 \\
Residual & 1446.408 & 28 & 51.657 & & \\
Total & 1894.000 & 29 & & & \\
\hline
\end{tabular}

Sumber: Data primer diolah, 2014 
Tabel anova menunjukkan hasil perhitungan f hitung sebesar 8,665 dengan tingkat signifikansi $0,006>\alpha$ yaitu sebesar 0,05. Dengan demikian, diketahui bahwa terdapat pengaruh yang signifikan antara variabel penggunaan dana zakat terhadap pemberdayaan masyarakat.

Hasil perhitungan statistik ordinary least square (OLS) ditunjukkan dengan t hitung. Secara terperinci hasil t hitungdijelaskan dalam tabel berikut:

\section{Tabel 8}

Coefficients

\begin{tabular}{|c|c|c|c|c|c|c|c|}
\hline \multirow{2}{*}{ Model } & \multicolumn{2}{|c|}{$\begin{array}{c}\text { Unstandardized } \\
\text { Coefficients }\end{array}$} & \multirow{2}{*}{\begin{tabular}{|l|} 
Standardized \\
Coefficients \\
Beta \\
\end{tabular}} & \multirow[b]{2}{*}{$t$} & \multirow[b]{2}{*}{ Sig. } & \multicolumn{2}{|c|}{$\begin{array}{l}\text { Collinearity } \\
\text { Statistics }\end{array}$} \\
\hline & B & $\begin{array}{c}\text { Std. } \\
\text { Error }\end{array}$ & & & & Tolerance & VIF \\
\hline $\begin{array}{l}1 \text { (Constant) } \\
\text { Penggunaan } \\
\text { dana Zakat }\end{array}$ & $\begin{array}{r}20,089 \\
1,294 \\
\end{array}$ & $\begin{array}{r}12,608 \\
, 439 \\
\end{array}$ & ,486 & $\begin{array}{l}1,593 \\
2,944\end{array}$ & $\begin{array}{l}, 122 \\
, 006 \\
\end{array}$ & 1.000 & 1.000 \\
\hline
\end{tabular}

Sumber: Data primer, diolah (2014)

Hasil penghitungan t hitung menunjukkan nilai t hitung menunjukkan bahwa nilai t hitung 2,944 dengan tingkat signifikansi 0,006 yang dibawah alpha yaitu sebesar 0,05. Dengan demikian, diketahui bahwa terdapat pengaruh yang signifikan antara variabel penggunaan dana zakat terhadap pemberdayaan masyarakat. Tabel 8 dapat diketahui hasil analisis regresi diperoleh koefisien untuk veriabel penggunaan dana zakat sebesar 1,294 dengan konstanta sebesar 20,089 sehingga dapat dibuat model persamaan regresi sebagai berikut:

\section{$Y=20,089+1,294 X$}

Berdasar persamaan regresi dapat diprediksi bahwa veriabel dependen akan berubah sebesar 1,294 untuk setiap unit perubahan yang terjadi pada veriabel independen. Akan tetapi dari hasil penelitian ini dapat disimpulkan bahwa variabel penggunaan dana zakat berpengaruh secara signifikan terhadap pemberdayaan masyarakat. 


\section{SIMPULAN, KETERBATASAN, DAN SARAN}

Berdasar hasil penelitian yang telah dilakukan mengenai pengaruh antara penggunaan dana zakat terhadap pemberdayaan masyarakat pada Badan Amil Zakat dan Lembaga Amil Zakat di Yogyakarta, maka dapat ditarik simpulan bahwa terdapat pengaruh antara penggunaan dana zakat terhadap pemberdayaan masyarakat pada Badan Amil Zakat dan Lembaga Amil Zakat di Yogyakarta. Keterbatasan dalam penelitian ini adalah sedikitnya data yang digunakan dalam penelitian karena Badan Amil Zakat dan Lembaga Amil Zakat belum banyak yang melaksanakan program pemberdayaan masyarakat.

Beberapa saran yang berkaitan dengan penelitian ini antara lain:

1) Bagi lembaga pengelola zakat

Hasil penelitian yang telah dilakukan bahwa penggunaan dana zakat mempunyai pengaruh terhadap pemberdayaan masyarakat. Sehingga penelitian ini dapat digunakan lembaga pengelola zakat agar dana zakat yang di peroleh dapat alokasikan untuk pemberdayaan masyarakat.

2) Bagi penelitian selanjutnya

Penelitian ini diharapkan dapat dikembangkan lagi dengan menambahkan variabel seperti tranparansi laporan keuangan penggunaan dana zakat dan perluasan konsep pemberdayaan masyarakat.

\section{DAFTAR PUSTAKA}

Anwas, Oos M. 2013. Pemberdayaan Masyarakat di Era Global. Bandung: Alfabeta.

Ardhanareswari, Resti. 2010. Analisis Sumber dan Penggunaan dana Zakat yang Berpengaruh terhadap Pemberdayaan Masyarakat. Bandung: Universitas Komputer Indonesia.

Asnaini. 2008. Zakat Produktif dalam Prespektif Hukum Islam. Yogyakarta: Pustaka Pelajar

Berita Ramadhan. 2012. [Online] Didapatkan: http://ramadhan.antaranews.com [17 februari 2014] 
Ghozali, Imam. 2011. Aplikasi Analisis Multivariate dengan Program IBM SPSS 19. Semarang: Universitas Diponegoro.

Hadi, Muhammad. 2010. Problematika Zakat Profesi dan Solusinya (Sebuah Tinjauan Sosiologis Hukum Islam). Yogyakarta: Pustaka Pelajar.

Hafidhuddin, Didin. 2008. Panduan Praktis tentang Zakat, Infak dan Sedekah. Jakarta: Gema Insani.

Hafidhuddin, Didin. 2002. Zakat dalam Perekonomian Modern. Jakarta: Gema Insani.

Huri, Daman, Moh. Miftahusyaian, Ronald J Warsa, Sutomo, dan Yudha Aminta. 2008. Demokrasi \& Kemiskinan. Malang: Averroes Press.

Ikatan Akuntansi Indonesia. 2011. Pernyataan Standar Akuntansi Keuangan No. 11 dan 70: Laporan Sumber dan Penggunaan Dana Zakat [online]. Didapatkan: http://www.iaiglobal.or.id [16 November 2013]

Indriantoro, Nur dan Bambang Supomo. 2012. Metodologi Penelitian Bisnis untuk Akuntansi dan Manajemen. Yogyakarta: BPFE UGM.

Muhammad. 2005. Pengantar Akuntansi Syariah. Jakarta: Salemba Empat.

Muhammad, Sahri, 2006. Mekanisme Zakat dan Permodalan Masyarakat Miskin, Malang: Bahtera Press.

Nurhayati, Sri dan Wasilah. 2012. Akuntansi Syariah di Indonesia. Jakarta: Salemba Empat.

Permendagri No.7 Tahun 2007: Kader Pemberdayaan Masyarakat [Online]: Didapatkan: http://agus34drajat.files.wordpress.com [Juni 2014]

Prastiya, Sulih, 2010, Kebijakan Kementrian Agama dalam Manajemen Zakat [Online]. Didapatkan: http://baznas.jogjakota.go.id [24 April 2014]

Putra, Ahmad Fajri. 2010. Pengaruh Pendayagunaan Zakat Produktif Terhadap Pemberdayaan Mustahiq Pada Badan Pelaksana Urusan Zakat Amwal Muhammadiyah (BAPELURZAM) Pimpinan Cabang Muhammadiyah 
Weleri Kabupaten Kendal. Skripsi. Semarang: IAIN Walisongo.

Putri, Niken Iwani Surya, 2012, Hikmah Keislaman [Online]. Didapatkan: https://ppmrindonesia.wordpress.com [16> November 2013]

Soemitra, Andri. 2009. Bank dan Lembaga Keuangan Syariah. Jakarta: Kencana.

Sugiyono. 2008. Metode Penulisan Kuantitatif, Kualitatif dan R\&D. Bandung: Alfabeta.

Undang-Undang Nomor 23 Tahun 2011: Pengelolaan Zakat [Online]. Didapatkan: http://lampung.kemenag.go.id [17 November 2013]

Utomo, Setiawan Budi. 2009. Metode Praktis Penetapan Nisab Zakat: Model Dinamis Berdasarkan Standar Nilai Emas dan Kebutuhan Hidup Layak (KHL) Provinsi. Bandung: Mizan Pustaka. 